\title{
POTENSI EKSTRAK DAN FRAKSI DAUN Gardenisa augusta SEBAGAI AGEN ANTIBAKTERI TERHADAP Staphylococcus aureus
}

\author{
Dewi Dianasari *1, I Wayan Seniarta ${ }^{1}$, Moch. Amrun Hidayat ${ }^{1}$ \\ ${ }^{1}$ Fakultas Farmasi, Universitas Jember, Jember, Indonesia \\ (dewi.dianasari@unej.ac.id, 081933300910)
}

\begin{abstract}
ABSTRAK : Pneumonia merupakan suatu infeksi yang terjadi pada parenkim paru. Pneumonia dapat disebabkan oleh berbagai macam mikroorganisme, salah satunya adalah bakteri Staphylococcus aureus. Kaca piring (Gardenia augusta) merupakan tumbuhan yang berpotensi dimanfaatkan sebagai agen antibakteri baru. Secara tradisional dapat dimanfaatkan untuk mengobati penyakit infeksi, seperti diare, disentri, dan infeksi vagina. Tujuan dari penelitian ini adalah untuk mengetahui aktivitas antibakteri ekstrak etanol dan fraksi daun kaca piring pada $S$. aureus. Pengujian dilakukan dengan metode difusi cakram terhadap kelompok uji dan kelompok kontrol. Kelompok uji terdiri dari ekstrak etanol dan fraksi daun kaca piring konsentrasi 10, 20, 30, 40, dan $50 \%$ b/v. Kelompok kontrol terdiri dari gentamisin cakram $10 \mu \mathrm{g}$ ( kontrol positif) dan DMSO 10\% (kontrol negatif). Hasil pengujian menunjukkan ekstrak etanol, fraksi heksana, dan fraksi etil asetat memiliki aktivitas antibakteri terhadap $S$. aureus, tetapi fraksi etanol air tidak menunjukkan adanya aktivitas antibakteri pada konsentrasi yang sama. Aktivitas antibakteri yang paling tinggi terlihat pada fraksi etil asetat. Golongan senyawa yang terkandung pada fraksi etil asetat, antara lain alkaloid, terpenoid, dan flavonoid. Kata kunci : antibakteri, daun kaca piring, fraksinasi, difusi cakram
\end{abstract}

\begin{abstract}
Pneumonia is an infection that occurs in the lung parenchyma. Pneumonia can be caused by a variety of microorganisms, one of which is the bacterium Staphylococcus aureus. Kaca piring (Gardenia augusta) is one of the plants that have the potential to be developed as a new antibacterial agent. Traditionally can be used to treat infectious diseases, such as diarrhea, dysentery, and vaginal infections. This study aims to determine the antibacterial activity of ethanol extract and fraction of kaca piring leaf on S. aureus. Antibacterial activity was tested by disc diffusion method on the test group and the control group. The test group consisted of ethanol extract and glass leaf plate fraction with concentrations of 10,20,30,40, and 50\% $w / v$. The control group consisted of $10 \mu \mathrm{g}$ gentamicin discs as positive controls and $10 \%$ DMSO as negative controls. The test results showed ethanol extract, hexane fraction, and ethyl acetate fraction had antibacterial activity on S. aureus, but the ethanol-water fraction did not show the presence of antibacterial activity at the same concentration. The highest antibacterial activity was seen in the ethyl acetate fraction. Group of compounds contained in the ethyl acetate fraction, including alkaloids, terpenoids, and flavonoids.
\end{abstract}

Keywords : antibacterial, kaca piring, fractionation, disc diffusion

\section{PENDAHULUAN}

Pneumonia hingga kini merupakan salah satu masalah kesehatan yang terjadi di seluruh dunia. Pneumonia menempati peringkat kedua sebagai salah satu sebab angka 
kematian balita di Indonesia yang cukup tinggi dengan jumlah kasus sebebas 3,55\%. ${ }^{10}$ Bahkan, terjadi peningkatan jumlah kasus pneumonia yang signifikan pada tahun 2017 dari 2016 sebesar 5,9\%. ${ }^{11}$

Bakteri S. aureus adalah bakteri normal pada manusia yang terdapat di daerah kulit, saluran pernapasan, dan pencernaan. Bakteri ini ditemukan sebanyak 20-50\% di dalam rongga hidung manusia, pakaian maupun benda lain yang terdapat di lingkungan sekitar. S. aureus dapat bersifat patogen dan invasif dengan menghasilkan enzim koagulase. ${ }^{3}$ S. aureus juga menjadi salah satu penyebab pneumonia yang terjadi pada balita di Indonesia. ${ }^{9}$

Tanaman merupakan salah satu bahan alam yang banyak dikonsumsi sebagai bahan pangan. ${ }^{18}$ Tanaman juga dapat dimanfaatkan sebagai bahan obat karena sebanyak $25 \%$ dari semua obat yang diresepkan berasal dari tanaman. ${ }^{14}$ Diperkirakan terdapat sebanyak 250 hingga 500 ribu spesies tanaman yang dapat digunakan dalam pengobatan, ${ }^{18}$ akan tetapi hanya sebanyak $15 \%$ yang telah dievaluasi kandungan fitokimia dan sebanyak $6 \%$ yang telah dievaluasi aktivitas biologisnya. ${ }^{14}$

Tanaman kaca piring (Gardenia augusta) dari suku Rubiaceae merupakan anggota genus Gardenia yang dapat digunakan untuk pengobatan. Secara tradisional, rebusan daun kaca piring dapat digunakan untuk mengobati beberapa penyakit seperti diare, disentri, dan infeksi vagina. ${ }^{13}$ Ditinjau dari berbagai macam senyawa kimia, seperti minyak atsiri, saponin, flovonoid, dan polifenol yang terkandung didalamnya, ${ }^{7}$ kaca piring berpotensi dikembangkan sebagai agen antibakteri. Berdasarkan uraian di atas, tujuan dari penelitian ini adalah untuk melakukan uji aktivitas antibakteri ekstrak etanol dan fraksi daun kaca piring terhadap S. aureus. Pengujian aktivitas antibakteri ekstrak etanol dan fraksi dilakukan menggunakan metode difusi cakram.

\section{ALAT DAN BAHAN}

Alat- alat yang digunakan yaitu neraca analitik, oven, vial, blender, erlenmeyer, beaker glass, pipet tetes, gelas ukur, autoklaf, cawan petri, tabung reaksi, rak tabung reaksi, jarum ose, gelas ekstrak, pipet volume, spreader, hot plate, bunsen, software ImageJ, batang pengaduk, loyang aluminium, rotary evaporator, vortex, laminar air flow, corong Buchner, inkubator, lemari es, mikropipet, yellow tip, blue tip, Standar Mc Farland 0,5. 
Semua bahan yang digunakan antara lain daun kaca piring yang diperoleh dari Kecamatan Umbulsari, Kabupaten Jember pada ketinggial $15 \mathrm{~m}$ dpl, bakteri S. aureus, etanol 96\% (teknis), gentamisin $10 \mu \mathrm{g}$, akuades steril, blank disc, $\mathrm{NaCl}$ 0,9\%, DMSO 10\%, Mueller-Hinton Agar (MHA), Nutrien Agar (NA), alkohol 70\%, aluminium foil, plastic wrap, kertas saring, kapas, kain kasa, etanol 96\%, heksana (teknis), dan etil asetat (teknis).

\section{METODE PENELITIAN}

Penelitian yang dilakukan adalah true experimental laboratories, bertempat di Laboratorium Fitokimia, Laboratorium Mikrobiologi dan Bioteknologi Bagian Biologi, dan Laboratorium Teknologi Sediaan Steril Bagian Farmasetika Fakultas Farmasi Universitas Jember mulai bulan April 2019 sampai November 2019.

Ekstraksi serbuk simplisia daun kaca piring menggunakan etanol $96 \%$ dengan perbandingan 1:10 dan menggunakan metode maserasi (3 hari), dan sesekali dilakukan pengadukan. Ekstrak yang diperoleh kemudian difraksinasi dengan metode partisi caircair, dengan pelarut heksana dan etil asetat secara berturut-turut. Pengujian antibakteri dilakukan dengan metode difusi cakram terhadap kelompok uji dan kelompok kontrol. Kelompok uji terdiri dari ekstrak etanol dan fraksi daun kaca piring konsentrasi 10, 20, 30, 40, dan 50\% b/v. Kelompok kontrol terdiri dari gentamisin cakram $10 \mu \mathrm{g}$ (kontrol positif) dan DMSO 10\% (kontrol negatif). Media uji yang telah diberi perlakuan diinkubasi selama 18 jam pada suhu $37^{\circ} \mathrm{C}$. Diameter zona hambat yang terbentuk diukur menggunakan jangka sorong sebagai interpretasi aktivitas dari agen antibakteri. Data hasil pengujian dianalisis dengan One way ANOVA dilanjutkan Post Hoc. Penapisan fitokimia pada ekstrak atau fraksi yang menghasilkan aktivitas antibakteri paling tinggi juga dilakukan.

\section{HASIL DAN PEMBAHASAN}

Hasil dari ekstraksi diperoleh massa ekstrak kering sebesar 40,52 gram, dengan rendemen ekstrak yang dihasilkan sebesar 20,25\%. Massa fraksi heksana, etil asetat, dan etanol air, berturut-turut adalah 0,54; 0,7; dan 6,06 gram, dengan rendemen fraksi masing-masing, sebesar 5,63; 7,29; dan 63,13\%. Difusi cakram merupakan metode awal yang digunakan untuk memprediksi dan mengevaluasi aktivitas antibakteri dari senyawa uji, seperti ekstrak tanaman, minyak esensial, metabolit sekunder, dan senyawa baru lainnya. Pemilihan menggunakan metode difusi cakram karena memiliki 


\section{J-PhMIII Jounnal of Pharmaceutical Care Anwar Meodka}

\section{Artikel Penelitian}

beberapa keunggulan, antara lain pengerjaannya yang sederhana, memerlukan biaya yang rendah, dan menghasilkan pengukuran yang baik. ${ }^{2}$

Gentamisin cakram sebagai kontrol positif menunjukkan sensitivitas tinggi pada $S$. aureus dengan nilai diameter zona hambat lebih dari $15 \mathrm{~mm} .{ }^{15}$ DMSO $10 \%$ sebagai kontrol negatif terbukti tidak memberikan aktivitas penghambatan pertumbuhan bakteri, sehingga tidak mempengaruhi hasil pengujian kelompok uji. Hasil pengujian dari ekstrak etanol, fraksi heksana, dan fraksi etil asetat daun kaca piring menunjukkan adanya aktivitas antibakteri terhadap $S$. aureus pada konsentrasi 10, 20, 30, 40, dan $50 \%$. Sedangkan, pada fraksi etanol air tidak memiliki aktivitas penghambatan pertumbuhan bakteri (Gambar 1).

Tabel 1. Data diameter zona hambat ekstrak etanol, fraksi heksana, fraksi etil asetat, dan fraksi etanol air daun kaca piring terhadap bakteri S. aureus

\begin{tabular}{|c|c|c|c|c|}
\hline \multirow{2}{*}{$\begin{array}{c}\text { Konsentr } \\
\text { asi }\end{array}$} & \multicolumn{4}{|c|}{ Diameter zona hambat sampel (mm) } \\
\hline & $\begin{array}{l}\text { Ekstrak } \\
\text { etanol }\end{array}$ & $\begin{array}{c}\text { Fraksi } \\
\text { heksana }\end{array}$ & $\begin{array}{c}\text { Fraksi etil } \\
\text { asetat }\end{array}$ & $\begin{array}{c}\text { Fraksi } \\
\text { etanol air }\end{array}$ \\
\hline $10 \%$ & $\begin{array}{c}6,45 \pm 0,09 \\
\text { a)(1) }\end{array}$ & $\begin{array}{c}6,63 \pm 0,03^{(a} \\
)(1)\end{array}$ & $\begin{array}{c}8,49 \pm 0,21^{(\mathrm{b})} \\
\text { (1) }\end{array}$ & $\begin{array}{c}0,00 \pm 0,00^{(\mathrm{c}} \\
\text { (1) }\end{array}$ \\
\hline $20 \%$ & $\begin{array}{c}7,16 \pm 0,12( \\
\text { a)(2) }\end{array}$ & $\begin{array}{c}7,20 \pm 0,12^{\text {(a }} \\
)(2)\end{array}$ & $\begin{array}{c}9,51 \pm 0,22^{(b)} \\
\text { (2) }\end{array}$ & $\begin{array}{c}0,00 \pm 0,00^{(\mathrm{c}} \\
)(2)\end{array}$ \\
\hline $30 \%$ & $\begin{array}{c}7,67 \pm 0,06 \\
\text { a)(3) }\end{array}$ & $\begin{array}{c}7,83 \pm 0,07 \\
\text { b)(3) }\end{array}$ & $\begin{array}{c}10,40 \pm 0,07 \\
\text { c)(3) }\end{array}$ & $\begin{array}{c}0,00 \pm 0,00 \\
\text { d)(3) }\end{array}$ \\
\hline $40 \%$ & $\begin{array}{c}8,55 \pm 0,12( \\
\text { a)(4) }\end{array}$ & $\begin{array}{c}8,63 \pm 0,20^{(a} \\
)(4)\end{array}$ & $\begin{array}{c}11,43 \pm 0,15 \\
\text { b)(4) }\end{array}$ & $\begin{array}{c}0,00 \pm 0,00^{(\mathrm{c}} \\
)(4)\end{array}$ \\
\hline $50 \%$ & $\begin{array}{c}9,34 \pm 0,13 \\
\text { a)(5) }\end{array}$ & $\begin{array}{c}9,65 \pm 0,21^{(\mathrm{a}} \\
)(5)\end{array}$ & $\begin{array}{c}12,44 \pm 0,26 \\
\text { b)(5) }\end{array}$ & $\begin{array}{c}0,00 \pm 0,00^{(\mathrm{c}} \\
)(5)\end{array}$ \\
\hline $\begin{array}{l}\text { Kontrol } \\
\text { positif }\end{array}$ & $\begin{array}{c}29,02 \pm 0,3 \\
9\end{array}$ & $29,11 \pm 0,42$ & $27,93 \pm 0,91$ & $28,79 \pm 0,44$ \\
\hline $\begin{array}{l}\text { Kontrol } \\
\text { negatif }\end{array}$ & $0,00 \pm 0,00$ & $0,00 \pm 0,00$ & $0,00 \pm 0,00$ & $0,00 \pm 0,00$ \\
\hline
\end{tabular}

Sumber: Data primer, 2020 


\section{Artikel Penelitian}

Gambar 1. Hasil pengujian dengan metode difusi cakram (A) ekstrak etanol, (B) fraksi heksana, (C) fraksi etil asetat, dan (D) fraksi etanol air dari daun Gardenia augusta terhadap $S$. aureus
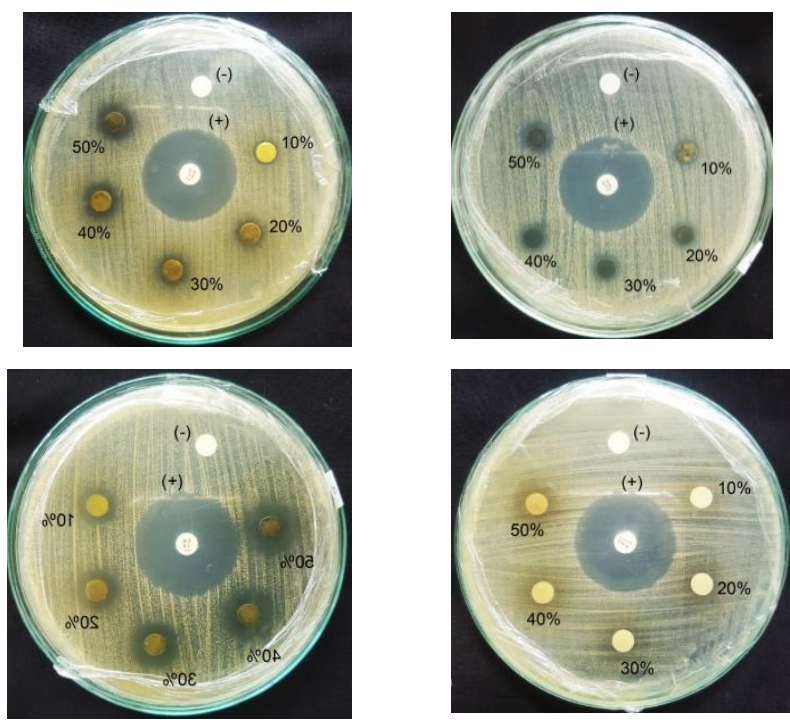

Sumber: Data primer, 2020

Hasil analisis statistik, data diameter zona hambat, (Tabel 1), nilai $\mathrm{p}<0,05$. Dapat diartikan bahwa terdapat perpedaan bermakna antar sampel uji yang berbeda pada konsentrasi yang sama. Ekstrak etanol dan fraksi heksana menunjukkan tidak adanya perbedaan signifikan $(\mathrm{p}>0,05)$ pada konsentrasi 10, 20, 40, dan 50\%, kecuali konsentrasi $30 \%$. Nilai diameter zona hambat pada semua konsentrasi uji dari ekstrak etanol, fraksi heksana, dan fraksi etil asetat menunjukkan hasil yang sebanding dengan peningkatan konsentrasi uji. Notasi angka yang berbeda antar konsentrasi uji pada sampel yang sama, menunjukkan adanya perbedaan yang bermakna $(p>0,05)$. Hal tersebut dikarenakan masing-masing konsentrasi uji pada tiap sampel menghasilkan aktivitas antibakteri yang berbeda (Tabel 1).

Aktivitas antibakteri yang paling tinggi terlihat pada fraksi fraksi etil asetat, jika dibandingkan dengan diamater zona hambat dari fraksi heksana, ekstrak etanol, dan fraksi etanol air. Jika dibandingkan konsentrasi 10\% dan 50\%, diameter zona hambat yang dihasilkan fraksi etil asetat adalah $8,49 \pm 0,21 \mathrm{~mm}$ dan $12,44 \pm 0,26 \mathrm{~mm}$, fraksi

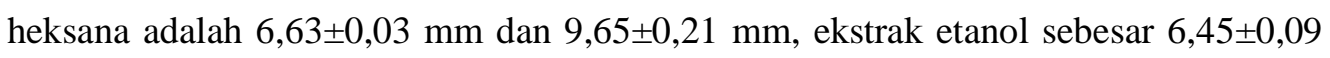

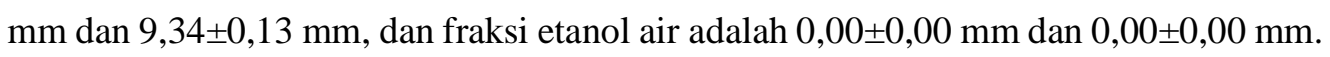
Hasil skrining fitokimia pada fraksi etil asetat mengandung beberapa golongan senyawa, antara lain alkaloid, terpenoid, dan flavonoid (Tabel 1). 
Senyawa golongan alkaloid yang terdapat pada genus Gardenia adalah genipin, yang termasuk alkaloid monoterpen. ${ }^{12}$ Senyawa tersebut memiliki aktivitas sebagai agen antibakteri. ${ }^{17}$ Senyawa terpenoid volatil utama kandungan dari genus Gardenia antara lain, linalool, trans- $\beta$-Osimena, z-3-hesenil tiglat dan $\alpha$-Farnesen yang yang berperan sebagai agen antibakteri. ${ }^{4}$ Senyawa golongan flavonoid yang terkandung pada genus Gardenia, yaitu quercetin, rutin, dan genistein, ${ }^{16}$ yang berperan sebagai agen antibakteri. $^{8}$

Aktivitas antibakteri alkaloid adalah dengan menghambat proses sintetis protein bakteri pada bagian enzim topoisomerase II. ${ }^{6}$ Sedangkan terpenoid bekerja dengan cara mengganggu dinding dan membran sel bakteri, menyebabkan denaturasi protein sitoplasma, dan inaktivasi enzim seluler yang menyebabkan kematian pada bakteri. ${ }^{1}$ Flavonoid sebagai agen antibakteri akan berinteraksi dengan protein ekstraseluler dan protein terlarut menjadi senyawa komplek yang akan mengganggu aktivitas dinding sel bakteri. ${ }^{5}$

\section{KESIMPULAN DAN SARAN}

Kesimpulan penelitian ini adalah aktivitas antibakteri daun kaca piring (G. augusta) terhadap $S$. aureus dari yang tertinggi hingga terendah berturut-turut, yaitu fraksi etil asetat, fraksi heksana, ekstrak etanol, dan fraksi etanol air serta golongan senyawa yang terkandung pada fraksi etil asetat, antara lain alkaloid, terpenoid, dan flavonoid. Adapun saran untuk penelitian lebih lanjut tentang isolasi senyawa aktif pada fraksi etil asetat daun G. augusta yang berperan sebagai agen antibakteri.

\section{DAFTAR PUSTAKA}

1. Badal, S. dan R. Delgoda. 2017. Pharmacognosy: Fundamentals, Applications and Strategy. Netherlands: Elsevier Inc. Hal 233-266.

2. Balouiri, M., M. Sadiki, dan S. K. Ibnsouda. 2016. Methods for in vitro evaluating antimicrobial activity: a review. Journal of Pharmaceutical Analysis. 6(2):71-79.

3. Brooks, G. F., K. C. Carroll, J. S. Butel, S. A. Morse, dan T. A. Mietzner. 2013. Jawetz, Melnick and Adelberg's: Medical Microbiology 26th Edition. United States of America: McGraw-Hill Education. Hal 199-203.

4. Chaichana, J., W. Niwatananun, S. Vejabhikul, S. Somna, dan S. Chansakaow. 2009. Volatile constituents and biological activities of Gardenia jasminoides. Journal of Health Research. 23(3):141-145. 
Artikel Penelitian

5. Ciocan, I. D. dan I. I. Bara. 2007. Plant product as antimicrobial agents. Secţiunea Genetică Şi Biologie Moleculară. 8:151-156.

6. Cushnie, T. P. T., B. Cushnie, dan A. J. Lamb. 2014. Alkaloids : an overview of their antibacterial, antibiotic-enhancing and antivirulence activities. International Journal of Antimicrobial Agents. 44(5):377-386.

7. Dalimartha, S. 2003. Atlas Tumbuhan Obat Indonesia Jilid 3. Jakarta: Trubus Agriwidya. Hal 30-31.

8. Farhadi, F., B. Khameneh, M. Iranshahi, dan M. Iranshahy. 2018. Antibacterial activity of flavonoids and their structure-activity relationship: an update review. Phytotherapy Research. 33(1):13-40.

9. Kementerian Kesehatan RI. 2010. Penumonia Pada Balita. Jakarta: Buletin Jendela Epidemiologi. Hal 17.

10. Kementerian Kesehatan RI. 2018. Profil Kesehatan Indonesia Tahun 2017. Jakarta: Kementerian Kesehatan RI. Hal 170-171.

11. Kochanek, K. D., S. L. Murphy, J. Xu, E. Arias, dan D. Ph. 2019. National vital statistics reports deaths: final data for 2017. National Vital Statistics Reports. 68(9):1-76.

12. Liu, X. dan H. Lou. 2007. Synthesis of monoterpene alkaloid derivatives from the iridoid glucoside geniposide. Natural Product Research. 21(13):1157-1164.

13. Romulo, A., E. A. M. Zuhud, dan J. Rondevaldova. 2018. Screening of in vitro antimicrobial activity of plants used in traditional Indonesian medicine. Pharmaceutical Biology. 56(1):287-293.

14. Rout, S., A. Jain, Choudary, dan Lopamudra. 2009. Plants in traditional medicinal system - future source on new drugs. International Journal of Pharmacy and Pharmaceutical Sciences. 1(1):1-23.

15. Tertel, M. L., J. P. Christopher, L. Martin, dan M. A. Russell. 2017. Performance Standards for Antimicrobial, 27th Edition. CLSI Supplement M100. Wayne. Pennsylvania: Clinical and Laboratory Standards Institute. Hal 62.

16. Wang, L., S. Liu, X. Zhang, J. Xing, Z. Liu, dan F. Song. 2016. A strategy for identification and structural characterization of compounds from Gardenia jasminoides by integrating macroporous resin column chromatography and liquid chromatography-tandem mass spectrometry combined with ion-mobility 


\section{J-PhMIII Jounnal of Pharmacouvical Care Anwar Meodka}

Artikel Penelitian

spectrometry. Journal of Chromatography A. 1-11.

17. Yang, L. I., Z. Zhen, Z. Jiawei, dan Z. Ye. 2016. A sensitive standardized method for determining antimicrobial activity of iridoid glycoside geniposide and its aglycone. Sciencepaper Online. 1-4.

18. Yuan, H., Q. Ma, L. Ye, dan G. Piao. 2016. The traditional medicine and modern medicine from natural products. Molecules. 21(599):1-18. 